\title{
Wat sê die boek Amos en Handelinge 15:15-17 oor die/'n beloofde land?
}

\author{
J.L. Helberg \\ Skool vir Bybelwetenskappe en Bybeltale \\ Potchefstroomse Universiteit vir CHO \\ POTCHEFSTROOM
}

\begin{abstract}
What do the book of Amos and Acts 15:15-17 say about the concept of the/a promised land?

This article explores the importance of the concept of land in the book of Amos and in Acts 15:15-17. In the discussion of this concept the epilogue of Amos is referred to. The conclusion arrived at implies that the concept of land - in an universal context - maintains an important place, even in the promise of a future existence. Even other nations will share in this new kingdom. The idea of a universal kingdom is so important in Acts that the concept the/a land is not the primary focus. This article indicates that this is also the case in the Heidelberg Catechism's interpretation of the fifth and tenth commandments. Some theological implications for the land issue in South Africa are pointed out and some conclusions drawn about the "Day of the Vow".
\end{abstract}

\section{Inleiding}

Land is so prominent in die verkondiging van die Ou Testament dat dit selfs 'n belangrike plek het in God se belofte aan sy volk Israel in die slot van die boek Amos, 'n belofte waarin die huidige aardse bedeling getransendeer word. Die vraag is of hierdie feit iets te sê het oor die (of 'n) land as beloofde land vir Israel en vir ander volke/nasies? Wat word in die slot van Amos geïmpliseer oor die betekenis en aard van die land of 'n land? Wat het dit vir ons vandag te sê, veral gesien in die lig van Handelinge 15 waarin 'n direkte verband gelê word tussen die Nuwe-Testamentiese tyd en die verkondiging in die slot van Amos? Watter lig werp Handelinge 15:15-17 se verwysing na Amos 9:11-12 op 'n aanspraak op die/'n land, voortvloeiende uit 'n geloofsverhouding met God en uit sy beloftes? ${ }^{1}$

1 Hier word nie op die betekenis van land elders in die Nuwe Testament ingegaan nie (vgl. daarvoor Helberg, 1998). Verder word die leser vir 'n breë bespreking en literatuurverwysing oor land in die Ou Testament en in die boek Amos verwys na Helberg (1997 en 1999). Vir die verskillende benaderings oor die verhouding tussen die res van die boek en die slot, kyk Smith (1989:277-280). 
In die slot van Amos word die gedeelte oor die herstel van die vervalle hut van Dawid (9:11-12) verbind met ' $n$ gedeelte wat in 'n eskatogiese beskrywing ' $n$ nuwe tyd van voorspoed en vrede in vooruitsig stel (9:13-15). Binne laasgenoemde tekening word die belofte gegee van die terugkeer na die land wat God vroeër vir Israel gegee het. Hierdie belofte gee konkrete beslag aan die aankondiging van ballingskap en die behoefte aan redding daaruit. Tegelykertyd open die gedeelte oor die herstel van die hut van Dawid en oor die verhouding met die nasies 'n nuwe perspektief. Daar moet dus in gedagte gehou word dat die verwysing na die land in die slot van Amos ingebed is in die eskatologiese beskrywing wat by die destydse werklikheid aansluit maar dit tegelykertyd transendeer.

Hierdie artikel dui aan dat daar in die slot van Amos 'n sekere verskuiwing in die betekenis en aard van die land, veral oor die funksie en doel, geïmpliseer word en dat Handelinge 15 daarby aansluit. Die universele betekenis van God se beloftes word vooropgestel en daarmee word ook die relatiewe en dienende funksie van land(e) getoon. Verder word vasgestel hoe die Heidelbergse Kategismus die kwessie van land hanteer en word kortliks gekyk na wat dit vir ons huidige situasie in hierdie land te sê het.

Daar sal aan die volgende punte ten opsigte van land aandag gegee word: hoe belangrik die plek van land in die Ou Testament is (insluitende die verhouding van land/plek en tyd); hoe land in die boek Amos gesien word (insluitende veranderings van benadering onder Israel na die tyd van Amos); die boek Handelinge se verkondiging van die koninkryk van God; hoe Handelinge 15:1517 die verkondiging van Amos verstaan; hoe die Heidelbergse Kategismus die vyfde en tiende gebod verklaar; hoe die landkwessie in Suid-Afrika bekyk moet word (insluitende die kwessie van beloofde land en gelofteland).

\section{Die belangrike plek van land in die Ou Testament}

Die Ou Testament is baie konkreet van aard. Zimmerli (1971; vgl. veral p. 7384) praat byvoorbeeld van "Die Weltlichkeit des Alten Testaments". Vir ons doel let ons daarop dat volgens die Ou Testament daar 'n belangrike verband tussen die mens en die bodem of grond is, maar ook 'n belangrike verskil. Die mens is van grond gemaak, nie uit die grond gebore nie. Sy eintlike betekenis kry die mens deur sy verhouding met God. Die mens is 'n lewende wese deurdat God die lewensasem in sy neus geblaas het (Gen. 2:7). Daarom het die mens heerskappy oor die bodem én 'n verantwoordelikheid teenoor die bodem. Hy is deur God in 'n tuin geplaas en moes dit bewerk en oppas (Gen. 2:15). Daar is nie 'n mitologiese band tussen die mens en die grond deurdat die grond/aarde vanself die mens voortgebring het en die mens net 'n aardemens, onderworpe aan die aarde is nie. 
Baie prominenter as die verhouding met die grond of bodem staan in die $\mathrm{Ou}$ Testament die verhouding tot ' $n$ land. Die plek en betekenis van land kan nie in 'n enkelvoudige formulering uitgedruk word nie. Land is ' $n$ gelaaide onderwerp waarin daar baie spanning opgesluit is. Israel se bestaan as volk word nie los van land gesien nie, maar altyd daarmee verbind. Land word ook nou verbind aan Israel se geloof en het 'n belangrike plek in die verbondsbeloftes (Gen. 15; 17; Weinfeld, 1993:xix-xx, 183; Brinkman, 1992:26; Kaiser, 1993:212). Aan die ander kant word Israel voortdurend daaraan herinner dat hulle nie van altyd af in die land is nie, maar deur Jahwe daarheen gebring is (Zimmerli, 1972:53; Preuss, 1991:133,136), en wel om sy teenwoordigheid te geniet (Brinkman, 1992:26).

Whitelam (1989:19-22, 30, 36) oordeel wel anders hieroor. Volgens hom is die weergawe van Israel se verkryging van die land in die Pentateug die vrug van later redaksies uit die na-ballingskapse tyd. Die terugkerende ballinge het die tradisies geherinterpreteer en in die vorm van beloftes gegiet. Dit het hulle gedoen ter fundering van hulle aanspraak op die land teenoor die afwysende houding wat die ingesetenes teenoor hulle ingeneem het. Die ingesetenes was dié wat nie in ballingskap gegaan het nie of in die tussentyd teruggekeer het. Hoe ook al teenoor hierdie opvatting van Whitelam geoordeel word, dit bly 'n feit dat die huidige weergawe van die Pentateug die beheersende in die $\mathrm{Ou}$ Testament is. Verder word die basiese teologiese waarde en betekenis van die land daarin vervat. Selfs 'n moontlike na-ballingskapse herinterpretasie verander nie hieraan nie.

Volgens die Ou Testament is Jahwe nie 'n God wat tot enige plek beperk is nie, maar is Hy die Skepper van hemel en aarde en die Regeerder oor alle dinge. Israel is nie uit die land gebore nie, maar is daarin geplant. Reeds voordat hulle 'n land gehad het, was hulle eintlik al 'n volk, met 'n besondere verhouding met Jahwe en in besit van die Tora, hulle basiese wet. Land is nie iets wat vanaf die skepping aan hulle verbind is nie (Preuss, 1991:144). Hulle bestaan word ook nie tot by die ontstaan van die skepping teruggevoer nie, soos trouens geen volk se bestaan deur die Ou Testament daarheen teruggevoer word nie: al die volke tot op Noag is deel van dieselfde voorgeslag (Von Rad, 1962:162). Die gedagte dat God Israel uitgekies het, met hulle 'n verbond gesluit het en hulle self na 'n land gelei het wat Hy vir hulle bestem het, lig Israel bokant die gedagte van gebondenheid aan 'n oerland uit. Hierdie feit beïnvloed ook Israel se verhouding, taak en roeping teenoor die ander nasies. Marquardt (1964:13) wys daarop dat die landgedagte in die geskiedskrywing van die Heksateug 'n groot rol speel en daarna altyd die denke van die Bybelskrywers besig hou, hoewel teologies gesien - nie een keer die hoofsaak is nie.

Israel besit ook nie werklik die land nie, maar het dit as iets ("erfdeel") wat eintlik aan Jahwe behoort. Hierdie feit het maatskaplike implikasies wat die verhouding met die medemens bepaal en tot voordeel van die armes, weduwees, 
weeskinders en vreemdelinge strek ('n beklemtoning wat sterk in die Psalms en die profete voorkom - vgl. byvoorbeeld Ps. 69:34; 107:41; Jes. 1:23; Jer. 7:6; Eseg. 18:16; Am. $2: 6 ; 4: 1 ; 5: 11-12$ ). Ware religie en 'n ware verhouding tot land/grond en die verhouding met die naaste, is deur Israel uit die oog verloor en veral deur Amos besonder sterk na vore gebring (Am. 3:10-11; 5:5-7, 10-12, 24$27 ; 6: 6-7 ; 8: 2,4)$.

Vir Israel was die gedagte van die land baie sterk verbind met Dawid (en Salomo). In daardie tyd was hulle 'n verenigde koninkryk in hulle eie land, veilig en voorspoedig onder eie bewind (Talmon, 1986:37). Vandaar die aansluiting in Amos 9:11-12 by Dawid.

Hoe belangrik plek of land ook mag wees, die kategorie van plek is ondergeskik aan die kategorie van tyd. In Genesis 1 is daar nie 'n indeling van plekke nie, maar wel van tyd (Westermann, 1974:157). Daarmee is plek se belangrike betekenis sowel as sy relatiewe betekenis aangesny. Dit geld des te meer vir land in besonder, wat nie ' $n$ skeppingsordening is nie, maar eers in die verloop van die geskiedenis ' $n$ belangrike rol begin speel het. Die land se betekenis lê veral daarin dat dit 'n simbool van die verlore woonplek van die mens is, naamlik die tuin van Eden. Dié is verloor deur die mens se sonde, maar in vooruitsig gestel deur die bemiddeling van die volk wat gebore sou word uit die roeping van Abraham (Gen. 12:1-3; Brueggemann, 1978:15-18). In die slot van Amos word hierdie uitbreiding van God se guns na die nasies in vooruitsig gestel. 'n Nuwe tyd sal aanbreek, daar sal universele vrede wees (Am. 9:13-14), Israel sal weer sy "grond" ontvang (9:15), maar dié sal uiteraard aan die nuwe situasie in die nuwe tyd diensbaar wees, wanneer die vervalle hut van Dawid weer opgebou sal word en die nasies in die heil sal deel (9:11-12). Die ruimtelike aspek is diensbaar aan dié van tyd en die vereistes wat dit stel.

\section{Hoe land in die boek Amos gesien word}

Land het in die boek Amos 'n belangrike plek, heel konkreet en in aansluiting by die geskiedenis: "Ek sal my volk weer in hulle grond plant, en hulle sal nie weer uitgeruk word uit die grond wat Ek hulle gegee het nie" (9:15). Tog is daar in die slot van Amos 'n verskuiwing na 'n meer universele betekenis, gesien binne die raamwerk van 'n eskatologiese situasie, wat weer aansluit by die situasie soos by die sondvloed en by die skepping (vgl. die vaste opeenvolging van seisoene en geseënde opbrengste; vgl. ook Smith, 1989:282). Hier word dus wyer perspektiewe geopen. Die "vervalle hut van Dawid" sal weer opgebou word en daar sal 'n oorwinning oor die nasies wees, maar so dat hulle sal deel in wat vir Israel beloof is (9:12-13; vgl. Helberg, 1998a:361 oor die oorblyfselkarakter wat in hierdie uitdrukking vervat is en wat die kleinheid en die veranderde, herbore en universele aard van hierdie begin met die verbondsvolk impliseer). 
Hierdie universele uitkyk blyk ook daaruit dat die woord wat in 9:15 gebruik word om die plek waarin Israel weer geplant sal word, aan te dui, nie die woord , soos byvoorbeeld by die roeping van Abraham nie (Gen. 12:1) nie, maar wat in Genesis 2 vir grond gebruik word. Die eskatologiese beskrywing in 9:13-15 laat hom geld en bring 'n verskuiwing na 'n meer universele atmosfeer (in aansluiting by 9:12-13), soos dié van Genesis 2. Al word die betekenis van land nie opgehef nie, word dit ingebed in ' $n$ raamwerk wat die huidige bedeling transendeer. Die tekening van die voortgang van seisoene (9:13) sluit aan by die universele situasie ná die sondvloed (Gen. 8:22; 9:8-17). Toe het God uit 'n hopelose situasie op 'n wonderbaarlike manier versoening tussen Hom en die mensdom daargestel.

In die boek Amos is land/plek/stad/tempel en tyd sterk ondergeskik gestel aan die religieus-etiese motief van reg en geregtigheid aan die naaste. Anders gestel, hier staan die wet/gebooie/gebeurtenis van Sinai sentraal, net soos dit histories "geplaas" is tussen die uittog en die intog, binne die geboortetyd van Israel as volk. Tog word in Amos nie direk na die gebooie of die wetgewing by Sinai verwys nie. Hierdie vereiste word eerder as 'n algemene, vanselfsprekende eis van God aan Israel (en aan heidene) aanvaar. So word daar ewe-eens in die slot van Amos nie uitdruklik na geregtigheid of bekering verwys nie, maar word dit veronderstel as ingesluit in die nuwe situasie. Hier is dus 'n atmosfeer waarin die wet nie as iets op sigself gesien word en waarin formele, wettiese eise gestel word nie. Dit is 'n atmosfeer heeltemal anders as dié van die Judaïste wat in die tyd van die apostels vereis het dat onderhouding van die wet van Moses noodsaaklik is om gered te word en dus ook vir gelowiges uit die heidennasies geld (vgl. hier onder).

In samehang met die religieus-etiese aksent, wat teenoor 'n formele, wettiese en dus onpersoonlike atmosfeer staan, wys die slot van Amos 'n mitologiese siening van sowel land (plek) as tyd af, 'n siening waarvolgens daar 'n eng, natuurlike of meganiese verband tussen God, land en volk bestaan en ook 'n sikliese benadering van tyd (oor laasgenoemde vgl. Heyns, 1997:239). Die konsep stad word nie genoem nie, maar ondergeskik gestel aan die konsep land - op grond van die konsep stad se noue verbintenis met mitologiese benaderings en praktyke. Land word uit die verlede en die eng, eksklusiewe verbinding met die verbondsvolk uitgelig en binne 'n universele raamwerk geplaas waarin die nasies deelhebbers aan die seën van Jahwe is. Ook tyd word uit sy mitologiese atmosfeer, waarin Israel dit verkeerdelik geplaas het, uitgelig deur die algehele verswyging van die Sabbat, en daar word 'n verband gelê met die voortyd van Noag en met die tuin van Eden. Tog is tyd, net soos die land, histories gewortel, soos blyk uit die verbinding met God se historiese optrede in die slotvers.

Ná die tyd van Amos het daar belangrike veranderings plaasgevind. 'n Intense skuldgevoel het onder die ballinge in Babilonië geheers en hulle toegewyd na God laat terugkeer. Volgens Weinfeld (1993:xix) was hulle doel nie 'n hernude 
verowering van die land nie, maar die hernuwing van die religieuse sentrum in Jerusalem. Die tempel en sy heiligheid, sowel as die onderhouding van die Tora was die primêre doelstelling van die mense wat uit die ballingskap teruggekeer het (vgl. die bespreking hier onder; vgl. ook Koenen, 1994:271 oor die benadering van heil vir die regverdiges en onheil vir die sondaars in hierdie tyd).

Die benadering was gewoonlik dat God deur die Gees teenwoordig is (vgl. Clements, 1965:130-134). Die ballingskapstyd het die oortuiging versterk dat Jahwe nie tot een land of een plek beperk is nie. Hy is die enigste God, Skepper van die hemel en die aarde (Jes. 63:15; 66:2). Land kry 'n verdiepte en meer simboliese betekenis, al impliseer dit nie dat daar met Suzanne Boorer (1992: 448-449) saamgestem hoef te word oor ' $n$ terugprojeksie in die Pentateug nie. Volgens haar word die stryd oor die kwessie van die vervulling van Jahwe se eed aan die voorouers oor die land geteken as verhale van die tyd van Moses. In hierdie tekening van die geslag van Moses beweeg hulle na die land toe en kom hulle by die kant van die land, maar gaan nooit in die land in nie. Hierdie voorstelling asof die eed oor die land nooit in vervulling gegaan het nie, wys volgens Boorer dat daardie latere geslag die werklikheid in die land beleef het as nie in ooreenstemming met wat hulle van die vervulling van die eed verwag het nie. Die "land" moet dus gesien word as simbolies van iets meer as slegs 'n stuk gebied of 'n geografiese lokaliteit.

In die laat-naballingskapse tyd word die land in Israel se eindtydse hoop 'n simbool van die hele aarde (vgl. Hahnart, 1983:126-128). Ook Davies (1974: $110-115,118)$ sien in die ballingskapse geskrifte 'n verskuiwing van belangstelling weg van die land na die breë menslike toe.

Nog 'n gevolg van die ballingskap was dat die belangrike betekenis van land na dié van stad toe verskuif het (Weinfeld, 1993:201). Volgens Weinfeld (1993:xx) het daar ook in verband met die land sowel as die stad Jerusalem 'n proses van vergeesteliking plaasgevind, maar anders as by die Christendom is nie daartoe geneig om die land en Jerusalem te stroop van hulle realistiese, aardse betekenis en om hulle bloot as simbole te sien nie. In dié Judaïsme is die werklike land en die fisiese Jerusalem altyd behou as die basis vir die geestelike waardes en simbole wat daarop rus.

\section{Die boek Handelinge se verkondiging van die koninkryk van God}

Die boek Handelinge vertel hoe Jesus wat tot in die hemel verhoog is, deur die uitstorting van die Heilige Gees sy volgelinge toegerus het om gehoorsaam te wees aan sy laaste opdrag, naamlik om sy getuies te wees (Hand. 1:8). Sy volgelinge het daarin belanggestel dat Hy die koninkryk vir Israel weer gaan oprig (v. 6). Sy antwoord daarop is die roeping wat Hy hulle oplê om die evangelie te verkondig, uitkringend vanaf Jerusalem na die hele Judea en 
Samaria en tot in die uithoeke van die wêreld. Sy koninkryk strek dus oor stadsen landsgrense heen en is universeel van aard. Dit gaan oor 'n wêreldgodsdiens, waarin daar 'n gelyke plek vir die verskillende nasies is. Hierdie universele aard word ook benadruk wanneer die Heilige Gees uitgestort word en elkeen van die teenwoordiges die evangelie in sy eie taal hoor (Hand. 2:8-11). Gelowiges uit die heidene is dus nie meer vreemdelinge en bywoners (soos die en in die $\mathrm{Ou}$ Testament nie), maar medeburgers en lede van die huisgesin van God en kry saam deel aan wat God belowe het (Ef. 2:12, 19; 3:6). Die begeerte van "in die land wees" word nou nou vervul deur "in Christus wees" (Wright, 1990:111; vgl. ook Clements, 1965:130-134 hierbo oor die feit dat God se teenwoordigheid in die ballingskaptyd gewoonlik in terme van die Gees geïnterpreteer word.)

In die Ou-Testamentiese bedeling was die koninkryk nog sterk verbind aan Israel as volk in die beloofde land, al was die verwagtings vir die toekoms gerig op 'n universele perspektief. Met die koms van Christus en die uitstorting van die Heilige Gees as vrug van sy opstanding en hemelvaart breek die evangelie kragtig deur na al die nasies toe en word die belofte dat al die volke in Abraham geseën sal word, vervul (Gen. 12:1-3; vgl. Rom. 5:5; Gal. 3:8-9, 14; Ef. 2:18; 3:6). Die Heilige Gees is nie volksgebonde nie en word ook nie op 'n land uitgestort nie, maar op mense, om vir God een volk - bestaande uit gelowiges te versamel (Hand. 2). Nou breek die teëpool van die gebeurtenis by Babel aan toe die mensdom uitmekaar gespat het en die nasies as 't ware teenoor God en sy volk gestaan het. Die muur van skeiding word afgebreek (Ef. 2:14), want die Gees van die Christus wat vir sondaars gesterf het en weer uit die dood opgestaan het, bring versoening (Ef. 2:18) - deur die geloof (Ef. 3:12). Die Gees bewerk 'n wedergeboorte, gee 'n nuwe perspektief, 'n omwenteling van houding teenoor alle dinge, 'n ongebondenheid en vryheid teenoor alle dinge in diens van die koninkryk van God. Dit is 'n ongebondenheid, voortvloeiend uit die ongebondenheid van die Gees: "Die wind waai waar hy wil. Jy hoor sy geluid, maar jy weet nie waar hy vandaan kom en waar hy heen gaan nie. So gebeur dit met elkeen wat uit die Gees gebore is" (Joh. 3:5, 8).

Die koms van Jesus vergeestelik egter nie die koninkryk van God nie. Daarvoor staan sy liggaamlike, stoflike geboorte en opstanding uit die dood te sentraal (Matt. 1:18-23; Hand. 1:3; Luk. 24:34). Die gemeenskap van die gelowiges is dan ook meer as net 'n deelhê aan geestelike seëninge en sluit ook liefde vir mekaar in die praktiese lewe in (1 Pet. 1:22; Wright, 1990:113). Teenoor die Sadduseërs leer Jesus Christus verder dat daar ook vir die gelowiges 'n liggaamlike opstanding uit die dood is (Matt. 22:23-32). Wat Jesus Christus wel doen, is om alles vanuit die almag en absolute heerskappy van God te benader (v. 29) en dit oor 'n persoonlike boeg te gooi ("Ek is die God van Abraham, die God van Isak, die God van Jakob", v. 32). Dit gaan om 'n onverbreeklike persoonlike verhouding tussen God en die gelowige ("Hy is nie die God van 
dooies nie, maar van lewendes", v. 32). Hierdie verhouding is die allesbeheersende. Alle ander dinge en verwagtinge staan in diens hiervan.

Daar is in die Bybelse godsdiens dus nie plek vir vergeesteliking nie, maar ook nie vir 'n materialistiese benadering nie (vgl. byvoorbeeld Calvyn, 1986:596597; De Greeff, 1984:120-122; 130-132, 262). In Jesus se verkondiging val die klem op die nuwe aarde (Matt. 5:5). Hoewel daar kontinuïteit tussen die nuwe aarde en die huidige aarde sal wees, sal daar ook 'n ingrypende verskil wees. Die liggaamlike opstanding hou byvoorbeeld nie in dat die liggaam dan presies so sal wees soos in die huidige bedeling, met dieselfde behoeftes en funksies, nie. Daar sal dan byvoorbeeld nie meer getrou word nie (Matt. 22:30).

'n Verdere bewys dat daar nie plek vir 'n materialistiese benadering is nie, blyk veral daaruit dat Matteus (22:34-40) hierdie gedeelte oor die opstanding verbind met die gedeelte oor die eis om God en die naaste lief te hê. Hierdie eis word deur Christus as die kern van die wet en die profete gestel. Ook in Handelinge 15 is verhoudinge sterk op die voorgrond, naamlik om mekaar te akkommodeer as Christene uit die Jodendom en Christene uit die heidene; om die verskillende behoeftes, benaderings en tradisies binne die eenheid te respekteer.

'n Belangrike wegwyser om te begryp dat land, ondanks sy belangrikheid in die Ou-Testamentiese verkondiging, tog 'n relatiewe betekenis het en aan 'n groter doel diensbaar is, is Paulus se verlange om saam met Christus te wees as verreweg die beste (Fil. 1:23). Die Ou-Testamentiese gelowiges het verlang om saam met die vaders in dieselfde grond, in die familiegraf, versamel te word. Hulle verlange was gekoppel aan die verwagting van die vervulling van God se beloftes, waarin die beloofde land 'n belangrike plek gehad het. Hierdie beloftes is in Christus vervul en het daarmee 'n nuwe, universele betekenis verkry. Dit is in wese dieselfde as die verkondiging in die Ou Testament dat God deur niks ingeperk kan word, nóg in 'n land (vgl. die dreiging van ballingskap, Am. 5:26; 9:4), nóg in 'n stad of tempel (vgl. die weiering dat Dawid vir Hom 'n tempel bou, 2 Sam. 7), nóg selfs in 'n naam (vgl. sy selfbekendstelling as "Ek is", Eks. 3:13-14).

\section{Hoe Handelinge 15:15-17 die verkondiging van Amos verstaan}

Wat die agtergrond van Handelinge 15 betref, sê Beyer (1951:91) dat daar in Antiogië 'n groot gemeente gebloei het waarin voormalige Jode en heidene in volle vryheid en eenheid saamgeleef het. Dit was 'n saamleef sonder die binding van die wet wat in Jerusalem 'n vanselfsprekende vereiste was. Vanuit hierdie gemeente sou 'n planmatige sendingaktiwiteit uitgaan. Ander soortgelyke heiden-Christengemeentes het ook ontstaan. Daarmee het daar 'n verskuiwing by die Christelike beweging plaasgevind; hy het hom losgemaak van die Jodendom in volkse en religieuse opsig en 'n wêreldbeweging geword. 
Handelinge 15:15-17 het kennelik meer as net Amos 9 op die oog en lui: "Simon het verduidelik hoe dit God self is wat begin het om na die heidennasies om te sien deur vir Hom 'n volk uit hulle te versamel. Die profete sê dieselfde. Daar staan geskrywe: Daarna sal Ek terugkom en Ek sal die vervalle huis van Dawid weer opbou ... sodat al die ander mense die Here kan soek, ja, al die heidennasies wat Ek geroep het om my eiendom te wees, sê die Here wat hierdie dinge doen". Hier is, in aansluiting by Griekse vertaling (Wolff, 1969:407), 'n enigsins ander lesing as in Amos 9:11-12. Hoe die saak presies in mekaar steek, is nie duidelik nie (vgl. daaroor Grosheide, 1948:40-41; MacGregor, 1954:202-203; Munck, 1973:140; Schmithals, 1982:138-139; De Villiers, 1983:24). Wat wel duidelik is, is dat die onversoenbare teenstelling tussen Israel en die "heidennasies" gesien word as deur God oorbrug en as die kern van die profetiese verkondiging in die geheel (Grosheide, 1948:38-39).

Ook Jeremia 12:14-16 kom in die visier. Hierdie gedeelte verkondig dat die heidennasies deur Jahwe uitgeruk sal word uit hulle grondgebied maar dat die Judeërs tussen húlle uitgeruk sal word. Jahwe sal Hom weer ontferm oor die Judeërs en sal hulle elkeen laat terugkom na sy besittings en na sy land toe. En as die buurvolke geleer het om in die Naam van Jahwe 'n eed af te lê, sal hulle 'n plek kry ("gebou word") onder sy volk ("my volk"). Die sin van terugkeer na die land(e) toe is dus om deel van die bouwerk van God se volk te wees.

Die gebruik van die woord weer ontferm), in Jeremia 12:15 gee blykbaar aanleiding tot die verbandlegging met "terugkom" in Handelinge 15:16: "Daarna sal Ek terugkom". Die terugkom sien op die wending by Jahwe om ontferming en genade te bewys. Hy bring nie net sy volk uit (die land van) die nasies uit nie, maar gee die nasies 'n deel onder sy volk. Hy versamel die nasies as (deel van) sy volk. Daarmee tree die land/lande as entiteite terug en vervul die funksie om gelowiges uit die volke vir die volk van Jahwe te lewer.

So word 'n nuwe betekenis gegee aan die terugkeer uit ballingskap na die land toe (Am. 9:15), naamlik om 'n ruimte te wees vir God se universele heilsdoel (vgl. vir hierdie universele visie Jes. 40-55, veral 42:6; 49:6; vgl. ook die feit dat lede van ander nasies plek kry in die land van Israel in Es. 47:21-23). Dan word dit duidelik waarom dit in verband met land/lande eintlik gaan en waaraan hulle ten volle diensbaar is: deelhê aan die volk-van-God-wees, redding deur te glo dat God self voorsien in wat nodig is om gered te word. Daarvoor gee Hy ook self sy Heilige Gees (Hand. 15:8).

Dit is God self wat terugkom, omkeer, 'n wending in Homself ondergaan, en daarom 'n omkeer

(Am. 9:14) by sy volk bewerk (vgl. Peels, 1997:10, 21-23, 25, 30 oor die grond vir die verandering wat in God self geleë is en ter wille van Homself is; vgl. ook O'Kennedy, 1997:100-102 oor verandering by God in Am. 7:1-6). Deur hierdie verandering vorm Israel as 't ware ' $n$ land of 
ruimte (soos wat hulle volgens die Nuwe Testament die tempel vorm) waarheen die heidennasies kan kom (sodat hulle Hom kan soek; vgl. ook Jes. 2; Miga 4). God wil gesoek word, deur Israel (sodat hulle kan lewe, Am. 5), maar ook deur die nasies universeel. So word Israel deur die boek Amos en in Jeremia 12:14-16 losgeskud uit nasionale voeë en uit 'n nasionale en bloot geografiese land.

Handelinge 15 sluit hierby aan. Die redding is vir almal, Joodse sowel as heiden-Christene, deur die geloof in God se genade in Christus alleen, sonder die wet. Dit staan teenoor die eis van mense uit Judea dat gelowiges uit die heidennasies nie gered kan word as hulle nie die wet en gebruik van Moses nakom deur hulle te laat besny nie $(15: 1,5)$. Hierdie benadering is dus: terug na die situasie soos by Moses, presies soos in die verlede, presies soos in Israel se omstandighede van destyds.

Die apostel Petrus se reaksie hierop is dat God hom uit Israel se geledere gekies het om die evangelie aan die heidennasies te verkondig sodat hulle kan glo. God het dit bevestig deur die Heilige Gees aan hulle te gee net soos aan Israel. Hy het geen onderskeid gemaak nie, maar ook die gelowiges uit die heidennasies se harte deur die geloof gereinig (15:8-9). "Ons, en ook hierdie gelowiges, glo dat ons net deur die genade van die Here Jesus gered word" (15:11).

Handelinge 15 bevat 'n sterk universalisering van skuld (vgl. ook Gal. 3:22). Dit is nie net Israel wat skuldig staan voor God nie, maar ook die heidennasies; ook andersom: nie net die heidennasies nie, maar ook Israel. Israel en die nasies word gelykgeskakel in skuld, maar ook in genade. Daarmee word die universele aard van Amos se oordeelsaankondiging (Am. 1-2), sowel as van die positiewe bemoeienis van God (9:7), tot sy volle konsekwensies gevoer. Daar is genade vir almal - deur in die Here Jesus te glo (15:11; vgl. ook Rom. 2:28-29; 3:26-29).

Die uitdrukking "Daarna sal Ek terugkom" (Hand. 15:15) vra nog meer van ons aandag as hier bo. "Terugkom" (anastrefo) beteken: "to move back to a point or area from which one has previously departed, but with more explicit emphasis upon the return - 'to move back, to return"” (Louw \& Nida, 1987:194). Die klem lê dus op die aksie van terugkeer. Dit is hierdie terugkom van God wat die oplossing bied, 'n terugkom waarin die terugkom van Israel en van die nasies inbegrepe is, terug na hulle land(e) toe, maar veral terug na God toe, want dit gaan nie om God se geografiese terugkom nie, maar veral om sy "geestelike" terugkom. Dit gaan om 'n herstelde verhouding met Hom (soos in Am. 9:15; vgl. ook veral Klaagl. 5:21). En die belang van hierdie verhouding is van so oorwegende belang dat die land(e) as geografiese entiteit(e) in Handelinge 15 heeltemal uit die gesig verdwyn. 


\section{Die Heidelbergse Kategismus se verklaring van land in die vyfde en tiende gebod}

Daar is twee gebooie waarin na land of grond verwys word, naamlik die vyfde gebod en die tiende gebod. Die vyfde gebod lui: "Eer jou vader en jou moeder, dan sal jy lank bly woon in die land wat Jahwe jou God vir jou gee" (Eks. 20:12. Deut. 5:16 is meer uitgebreid maar wesenlik dieselfde). Dit gaan hier om gehoorsaamheid aan die ouers; die land is sekondêr in die sin dat dit 'n vrug van hierdie gehoorsaamheid is. Die Heidelbergse Kategismus gee in sy verklaring (vraag 104) geen aandag aan hierdie deel van die gebod nie. Dit is in die gees van Efesiërs 6:2-3 waarin die belofte om in die land te woon, heeltemal universeel verstaan word: "sodat dit met jou goed mag gaan en jy lank mag lewe op die aarde".

In die tiende gebod bring Deuteronomium 5:21 ook die naaste se grond ter sprake (omrede die waarde wat land/grond later, in die ballingskapstyd, verkry het?) as iets wat nie begeer mag word nie. Ook hierop gaan die Heidelbergse Kategismus nie in nie. Die afsluitende verklaring oor die streng vereistes van die tien gebooie (vraag 115) is hier van belang. Dit raak die vergewing van sondes deur die genade in Christus en dit raak die Heilige Gees. Albei hierdie aspekte het ' $n$ belangrike plek in Handelinge 15. Eerstens gaan dit in die gebooie om ons sondige natuur te leer ken en met groter verlange na die vergewing van sondes en na die geregtigheid van Christus te soek. Tweedens moet ons God om die genade van die Heilige Gees bid sodat ons hoe langer hoe meer na die ewebeeld van God vernuwe mag word totdat ons ná hierdie lewe die volmaaktheid as doel bereik.

Ook die boek Galasiërs handel oor verlossing deur geloof alleen - verlossing sonder die wet (2:16). Ook hier word na die Heilige Gees verwys. In Galasiërs val belangrike lig op ons onderwerp en op die Heidelbergse Kategismus (vraag 115). Deur te glo aan God se genade deur die Here Jesus Christus, kry 'n mens deel aan die Heilige Gees (Hand. 15:8; Gal. 3:2, 5, 14). Jy word 'n erfgenaam van God (Gal. 3:29). Die erfenis word nie in materiële terme, soos land, uitgespel nie. Grond (akker) kom slegs oordragtelik ter sprake, toegespits op die ewige lewe ("Wie op die akker van sy sondige natuur saai, sal van die sondige natuur dood en verderf oes. Maar wie op die akker van die Gees saai, sal van die Gees die ewige lewe oes", Gal. 6:8). Dit gaan om God as Vader te hê (Gal. 3:6) en as sy kind te leef. Dit is om vry te wees van alle bindinge (Gal. 5:13), om in jou gedrag deur die Gees beheers te wees (Gal. 5:25) en mekaar in liefde te dien, want die hele wet word in hierdie een gebod saamgevat: "Jy moet jou naaste liefhê soos jouself" (Gal. 5:13-15). Die persoonlike verhouding eerder as die territoriale faktor, is die allesbeheersende.

Die Heidelbergse Kategismus praat dus tereg van die Heilige Gees en die vernuwing na die ewebeeld van God (kindskap) en sien hierdie volmaaktheid as 
die doel van die mens se lewe. Dit alles is die vrug van die geloof in die verlossing deur Christus, deur die evangelie alleen. Reeds die slot van Amos maak 'n appèl op die geloof in God se genade alleen as die grond vir die herstel van Israel (vgl. die ontbreking van enige vereistes). Ook daar trek alles saam in die verhouding tussen God en sy volk ("my volk", "julle God", 9:15).

Die Heidelbergse Kategismus plaas dus die allesbeheersende klem waar dit volgens Handelinge 15 en Galasiërs geplaas word: erfgename wees van die geestelike erfenis, kind van God wees, daarvolgens leef deur liefde te beoefen en 'n mens se verwagtings te laat opgaan in die verhouding van liefde met God.

Daar moet wel in gedagte gehou word dat die Heidelbergse Kategismus ook nie die inleiding tot die gebooie verklaar nie, naamlik "Ek is die Here jou God wat jou uit Egipte, uit die plek van slawerny, bevry het" (Eks. 20:2). Hierin word God se verbondsverhouding met Israel en die uittog aangesny. Die vraag is natuurlik of die Kategismus dit wat hy verklaar, getrou aan die verband (en in die lig van Christus) doen. As doel van die onderhouding van die gebooie word gestel: dankbaarheid en lof aan God; sekerheid van 'n mens se geloof te hê en 'n mens se naaste vir Christus te kan wen (H.K. 32:86). Dit word binne 'n verbondsraamwerk gesien: "Omdat Christus ons, nadat Hy ons met sy bloed gekoop het ...". Hierdie perspektief is in ooreenstemming met die stelling "Ek is die Here jou God" in die inleiding tot die gebooie. Hierteenoor bly die algehele afwesigheid van die hantering van die landelement in die twee gebooie in die Heidelbergse Kategismus opvallend en wys dit op die relatiewe waarde wat daarin aan land in die koninkryk van God toegeken word (vgl. ook die bespreking bo).

\section{Die landkwessie in Suid-Afrika}

Land en grond is vandag in die besonder ' $n$ onderwerp van belangstelling in Suid-Afrika. Verskillende bevolkingsgroepe, of van die lede van die verskillende groepe, kyk verskillend na die betekenis van die land as geheel, afgesien van hoe die grense daarvan gesien word. Daar is verder baie kwessies oor eienaarskap van grond, onteiening, aanspraak, restitusie, "herverdeling", solidariteit, perke aan staatsgesag, ensovoorts (vgl. byvoorbeeld Wittenberg, 1991:58-60; Strydom, 1995:398-413). Dit is nie die diel van hierdie artikel om op hierdie sake in te gaan nie, maar slegs om op enkele (teologiese) aspekte te wys wat op grond van ons onderwerp belangrik kan wees.

Die onderhawige sake het natuurlik baie historiese en sosiologiese fasette wat in ag geneem moet word. Daar is nie alleen 'n verskil in benadering tussen verskillende bevolkingsgroepe nie, maar ook binne die groepe, samehangend met teologiese sienings en vooronderstellings (vgl. byvoorbeeld Kawale, 1993:11-13) en met die mate van verstedeliking. 'n Stelling soos "Afrika wil sê: die stuk grond behoort nie aan meneer $\mathrm{M}$ nie, maar meneer $\mathrm{M}$ behoort aan die 
grond" (Swanepoel, 1997:115), geld dus seker nie onder alle swart mense van Afrika ewe sterk nie. Dieselfde geld vir die stelling van Boesak (1997:126): "Verder word in die Afrika-godsdiens aanvaar dat mense op 'n mistieke wyse verbind is aan die land waarop hul woon. Daarom is die grond vir hulle heilig en onskendbaar. Om te bly woon op die familiegrond verseker 'n mistieke band met die voorouers. Daarom lei vervreemding van die grond tot onheil in die gesins- en familielewe". (Vgl. ook Kawale [1993:44] oor die neiging tot vergoddeliking van die natuur in die Afrikakultuur.)

Daar is verder ook ' $\mathrm{n}$ verskil in benadering van dié wat voorvadergeeste aanbid en dié wat daarvan afstand gedoen het - hoe groot of klein die persentasie van laasgenoemdes ook mag wees. In elk geval is die benadering soos in genoemde stelling vervat, nader aan die mitologiese benadering van Israel se tydgenote. Hierdie benadering het soms ook wel sy invloed op die volk Israel self laat geld en daarteen het onder andere Amos sterk standpunt ingeneem.

Vir 'n grondige benadering van die landkwessie sal ook genuanseerd gedink moet word oor, enersyds "skeppingsgeloof" met sy universele inslag in die $\mathrm{Ou}$ Testament, en, andersyds, die historiese benadering van die Ou Testament waarin God se verkiesing van Israel en sy verbond met Israel 'n sentrale plek inneem (vgl. oor laasgenoemde Van Rooy, 1997:311-326). Laasgenoemde aspek ontbreek byvoorbeeld in die artikel van Boesak. Die gedagte van 'n oerverbintenis met die land of 'n stuk grond is afgesny, soos in punt 2 hierbo aangedui.

Ook Suid-Afrikaners van Europese afkoms het verskillende benaderings oor land, soos byvoorbeeld dié wat 'n volkstaat voorstaan en dié wat dit nie voorstaan nie; of soos stedelinge en plattelanders. In die stad word die kwessie van land gewoonlik baie relatiewer, veral na gelang die proses van verstedeliking reeds oor lang tydperke strek. Stad vereis dat mense van verskillende tale en kulture saam moet woon. 'n Sterk geworteldheid in 'n bepaalde stuk(kie) grond ontbreek dikwels en beweeglikheid na ander huise/grond is eerder aan die orde van die dag. Sosiologiese faktore en dryfvere speel dus 'n belangrike rol na gelang van verskillende omstandighede. Afgesien hiervan is dit belangrik om ook in hierdie opsig moontlike mitologiese tendense en teologies-historiese benaderings van mekaar te onderskei.

Dit lê buite die fokus van hierdie artikel om op hierdie sake in te gaan. 'n Saak wat hier nog wel aandag verdien, is dié van beloofde land en/of gelofteland. Geloftedag het sterk aansluitingspunte by die gedagte van 'n beloofde land. Ook oor Geloftedag bestaan daar verskillende benaderings en beoordelings. Boesak (1997:123) skryf byvoorbeeld:

As wraakaksie (sic!) het die Voortekkers meer as 3000 impi's by die slagveld te Bloedrivier gedood. Hierdie militêre oorwinning het 'n sterk 
godsdienstige betekenis verkry en die Afrikaner se begrip van land beïnvloed. 'n Sombere (sic!) eed is afgelê dat dié dag elke jaar en vir altyd aan God toegewy sou word. In hierdie tyd het die trekkers hulle veral vereenselwig met oud-Israel se roeping om die 'beloofde land' verder binne te gaan. Dit het natuurlik die onderwerping van die inheemse volkere van dié land ingehou, en 'n teologie is opgebou om dit te regverdig.

Van Afrikanerkant sal hierdie saak seker anders beoordeel word. Ook hierop kan nie in hierdie artikel nader ingegaan word nie.

Daar is wel nog ' $n$ aspek wat hier aandag verdien: daar is ' $n$ belangrike verskil tussen beloofde land en gelofteland. 'n Gelofteland spruit nie uit God se belofte nie, maar uit 'n menslike gelofte aan God. Daar word in die gelofte oor Geloftedag niks oor land of plek gesê nie, maar dit gaan tog wel om 'n bestaansmoontlikheid in 'n bestaansruimte. Geloftedag word sterk verbind aan verbondenheid aan hierdie bodem/land. Die gelofte het te doen met onderhouding van 'n bepaalde tyd, gekoppel met die sabbat of rusdag. (Hierdie koppeling geld in die praktyk, al word die historiese grond hiervoor deur baie bevraagteken.) Die feit dat die dag volgens die gelofte "soos" 'n sabbat onderhou sal word en dus nie sonder meer met die Bybelse rusdag gelykgestel word nie, verander nie aan die feit dat hier 'n sterk verband met die sabbat of rusdag gelê word nie. Die verbinding is des te sterker deurdat die onderhouding van dié dag in die gelofte gekoppel is aan die oprigting van 'n kerkgebou.

Volgens die Nuwe Testament kry die sabbat of rusdag in Christus 'n nuwe en universele betekenis (Matt. 12:8; Mark. 2:27; Kol. 2:16-17). Juis daarom kan Geloftedag, gesien sy noue verbinding met die rusdag, nie by ' $n$ bepaalde plek, land of dag vashaak nie, maar is hy diensbaar aan die koninkryk van Hom aan wie die gelofte gedoen is. In Christus is die eksklusiwiteit van die rusdag vervang deur inklusiwiteit. Daar word wel verskillende vereistes aan Christene uit die Jode en Christene uit die heidene gestel, volgens hulle verskillende omstandighede, maar hulle werk saam aan die een doel van die koninkryk.

As die verbandlegging van Geloftedag met die sabbat/rusdag nie in hierdie universele perspektief ingebed is nie, is die verbandlegging ongegrond en is dit 'n monopolisering daarvan vir nasionale doeleindes. Die Christelike rusdag (en samekoms in die "huis van God") getuig juis van 'n transendering van nasionale grense en van, deur Christus, versoening met God en met (gelowiges uit) ander volke. Dit sluit toespitsing van die onderskeie groepe op "eie" agtergrond, geskiedenis en taak nie uit nie, maar dit impliseer wel die uitreik na ander. Om dié wat die kern van die gelofte deel en nader wil staan, in te sluit, is 'n logiese uitvloeisel en 'n noodsaaklike vereiste vir die vervulling van die gelofte. Al kan Geloftedag dus nie sonder meer met 'n dag van versoening gelykgestel word nie, het dit sterk aansluitingspunte vir so iets. Wat ook al die probleme in verband met die uitsorteer van land- en grondkwessies is, hulle vir wie die 
koninkryk van God die hoofsaak is, het ruimte om saam daaraan diensbaar te wees.

\section{Samevatting en gevolgtrekkings}

Die slot van Amos gee aan die land 'n plek in die verwagtings van die herstel van Israel, maar binne 'n universele verband en 'n eskatologiese skildering. Handelinge trek die lyn nog verder universeel deur na die gelowiges uit al die nasies. Die hele fokus is op die nuwe volk van God uit Joodse én heidense afkoms. Dit vra akkommodering van mekaar, gesien teen mekaar se onderskeie agtergronde, tradisies en behoeftes, maar binne die een volk van God wat alleen uit die geloof in die genade van God deur Christus gered word en deur die een Gees van God saamgebind en gelei word.

Die Heidelbergse Kategismus gaan glad nie in op die grond- of landaspek in die vyfde en tiende gebod nie, maar betrek alles op die persoonlike verhoudinge: die verlossing deur Christus en die lewe deur die Gees om na die ewebeeld van God vernuwe te word. Dit is in ooreenstemming met die tendens in die ballingskapstyd om die teenwoordigheid van God nie in terme van 'n plek nie, maar in terme van die Gees te sien. Die besit van 'n ruimte of land/grond kom nie in die Heidelbergse Kategismus ter sprake nie en die nadruk is op die besit van die Heilige Gees, of, beter, om in besit van die Heilige Gees te wees. Dit gee ware vryheid in Christus, 'n vryheid waarin die dryfveer is om in diens te wees van die wêreldwye koninkryk van God.

In die nuwe bedeling wat met Christus se koms aangebreek het, gaan dit nie om die oprigting van die koninkryk van Israel of van enige ander volk nie. In die universele koninkryk van God is materiële dinge nie sonder waarde nie, soos blyk uit die belangrikheid van die liggaamlike opstanding van Christus en van die gelowiges. Tog is materiële dinge diensbaar en die klem val op die nuwe aarde (Matt. 5:5). Tussen die nuwe aarde en die huidige aarde sal daar kontinuïteit wees, maar ook 'n ingrypende verskil, soos tussen die huidige liggaam en die opstandingsliggaam.

Die verabsolutering van bepaalde belangrike dinge is 'n wesenlike gevaar vir die geloofslewe. Selfs so 'n belangrike saak soos die wet is deur Israel verabsoluteer, sodat dit 'n struikelblok vir die geloof en vir onderlinge verhoudinge tussen groepe geword het. Dit was nodig dat die wet drasties van nasionale en teologiese ballas gestroop moes word om sy regmatige plek binne die koninkryk te verkry. Des te meer is volkskap en/of grond of land, vatbaar vir verabsolutering en het dit nodig om van historiese, teologiese en mitologiese ballas gestroop te word ten einde 'n nugter en wedersydse akkommoderende benadering moontlik te maak. Dit geld veral binne die huidige Suid-Afrikaanse samelewing met sy verskillende groeperinge en verskille in geskiedenis, kultuur 
en agtergrond, besonderlik oor die land- en grondkwessie wat tans skerp in die kalklig is.

As die land- en grondkwessie in Suid-Afrika teen hierdie agtergrond van Amos, die Nuwe Testament en die verklaring van die Heidelbergse Kategismus bekyk word, kan dit versoberend inwerk en help om mitologiese, bloed- en bodembenaderings, waarin emosie en polarisering die botoon voer, te ontwyk.

Amos en Handelinge 15 gee ook lig vir 'n benadering van Geloftedag gesien binne sy historiese verband, maar tegelykertyd sonder eksklusiwiteit en binne 'n universele roepingsbewustheid.

\section{Bibliografie}

BEYER, H.W. 1951. Die Apostelgeschichte. Göttingen : Vandenhoeck \& Ruprecht. (Das Neue Testament Deutsch.)

BOESAK, W. 1997. 'n Swart teologie van die land: die Suid-Afrikaanse problematiek. (In Jones, C. \& Hulley, L., reds. Wonder jy ook oor ...? Gedagtes oor omstrede kwessies van ons dag. Kaapstad : Lux Verbi. p. 120-130.)

BOORER, Suzanne. 1992. The promise of the land as oath. (Beihefte zur Zeitschrift für alttestamentliche Wissenchaft. 205.) Berlin : De Gruyter.

BRINKMAN, J. 1992. The perception of space in the Old Testament. Kampen : Kok Pharos.

BRUEGGEMANN, W. 1978. The land. London : SPCK.

CALVYN, J. 1986. Institusie van die Christelike godsdiens. II. Potchefstroom : CJBF.

CLEMENTS, R.E. 1965. God and temple: the idea of the divine presence in ancient Israel. Oxford : Blackwell.

DAVIES, W.D. 1974. The gospel and the land. Los Angeles : Universiy of California Press.

DE GREEF, W. 1984. Calvijn en het Oude Testament. Groningen : Bolland. (Th.D.-proefskrif - Utrecht.)

DE VILLIERS, 1983. Die Handelinge van die Apostels. II. Kaapstad : NG Kerk-Uitgewers.

GROSHEIDE, F.W. 1948. Die Handelingen der Apostelen. II. Amsterdam : Bottenburgh.

HAHNART, R. 1983. Das Land in der spätnachexilischen Prophetie. (In Strecker, G., red. Das Land Israel in Biblischer Zeit. Jerusalem Symposium 1981 der Hebräischen Universität und der Georg-August-Universität. Göttingen : Vandenhoeck \& Ruprecht. p. 126-140.)

HELBERG, J.L. 1997. Goddelike onberekenbaarheid en menslike toerekenbaarheid in die boek Amos. In die Skriflig, 31(4):403-419.

HELBERG, J.L. 1998. Understanding the concept of land in the Old and New Testament: the importance of a personal factor. Koers, 63(3):225-240.

HELBERG, J.L. 1998a. Amos: 'n teologie van bedreiging? In die Skriflig, 32(3):349-362.

HELBERG, J.L. 1999. Die betekenis van land in die slot van die boek Amos. In die Skriflig, 33(2):273-289.

HEYNS, Dalene. 1997. Space and time in Amos 8: An ecological reading. Old Testament Essays, 10(2):236-251.

KAISER, O. 1993. Der Gott des Alten Testaments. Theologie des Alten Testaments. I. Göttingen : Vandenhoeck \& Ruprecht.

KAWALE, W.R. 1993. A theological critique of the reinterpretation of the relationship between the concepts of God in the Old Testament and in the African traditional religions. Stellenbosch : University of Stellensch. (Th.M. thesis.) 
KOENEN, K. 1994. Heil den Gerechten - Unheil den Sündern! Ein Beitrag zur Theologie der Prophetenbücher. Berlin : Walter de Gruyter. (Beihefte zur ZAW. 229.)

LOUW, J.P. \& NIDA, E.A. 1987. Greek-English Lexicon of the New Testament. 1. New York : United Bible Societies.

MacGREGOR, G.H.C. 1954. The Acts of the Apostels. (The Interpreter's Bible.) New York : Abingdon.

MUNCK, J. 1973. The Acts of the Apostels. (The Anchor Bible.) New York : Doubleday.

MARQUARDT, F.W. 1964. Die Bedeutung der biblischen Landverheissungen für die Christen. München : Kaiser. (Theologische Existenz Heute. 116.)

O'KENNEDY, D.F. 1997. 'It shall not be'; Divine forgiveness in the intercessory prayers of Amos (Am. 7:1-6). Old Testament Essays, 10(1):92-108.

PEELS, H.G.L. 1997. De omkeer van God in het Oude Testament. Apeldoorn : Theologische Universiteit Apeldoorn. (Apeldoornse Studies. 34.)

PREUSS, H.D. 1991.Theologie des Alten Testaments. I. Stuttgart : Kohlhammer.

SCHMITHALS, W. 1982. Die Apostelgeschichte des Lukas. (Züricher Bibelkommentare.) Zürich : Theologischer Verlag.

SMITH, G.V. 1989. Amos. Grand Rapids : Zondervan.

STRYDOM, J.G. 1995. Redistribution of land: the eighth century in Israel, the twentienh century in South Africa. Old Testament Essays, 8(3):398-413.

SWANEPOEL, J.F. 1997. My hart wil Afrika. Kaapstad : Queillerie.

TALMON, S. 1986. King, cult and calender in ancient Israel. Jerusalem : Magness Press, Hebrew University.

VAN ROOY, J.A. 1997. The covenant with Abraham in the context of Africa. In die Skriflig, 31(4):311-326.

VON RAD. G. 1962. Old Testament Theology. I. Edinburgh : Oliver \& Boyd.

WEINFELD, M. 1993. The promise of the land: The inheritance of the land of Canaan by the Israelites. Berkeley : University of California Press.

WESTERMANN, C. 1974. Genesis. Neukirchen-Vluyn: Neukirchener Verlag. (Biblischer Kommentar Altes Testament.)

WHITELAM, K.W. 1989. Israel's traditions of origin: reclaiming the land. Journal for the Study of the Old Tstament, 44:19-42.

WITTENBERG, G.H. 1991. The significance of land in the Old Tstament. Journal of Theology for Southern Africa, 77:58-60.

WOLFF, H.W. 1969. Dodekapropheten. 2. Joel und Amos. (Biblischer Kommentar Altes Testament.) Neukirchen-Vluyn : Neukirchener Verlag.

WRIGHT, C.J.H. 1990. God's people in God's land: family, land, and property in the Old Testament. Grand Rapids : Eerdmans.

ZIMMERLI, W. 1971. Die Weltlichkeit des Alten Testaments. (VR Kleine VandenhoeckReihe.) Göttingen : Vandenhoeck \& Ruprecht.

ZIMMERLI, W. 1972. Grundriss der alttestamentlichen Wissenschaft. (Theologische Wissenschaft.) Stuttgart : Kohlhammer. 